\title{
Observations on the Protection of Refugees in Indonesia
}

\author{
Fithriatus Shalihah $^{1}$, Muhammad Nur ${ }^{2}$ \\ ${ }^{1}$ Universitas Ahmad Dahlan, Indonesia, \\ E-mail:fithriatus.shalihah@law.uad.ac.id \\ ${ }^{2}$ Universitas Ahmad Dahlan, Indonesia, \\ E-mail:muhammad.nur@law.uad.ac.id
}

Submitted: April 22, 2021; Reviewed: May 24, 2021; Accepted: May 28, 2021

\begin{tabular}{|c|c|}
\hline Article Info & Abstract \\
\hline $\begin{array}{l}\text { Keywords: } \\
\text { Refugee Status, Refugee Protection. } \\
\text { DOI: } \\
\text { 10.25041/fiatjustisia.v15no4.2143 }\end{array}$ & $\begin{array}{l}\text { Pekanbaru City and Makassar City are areas that } \\
\text { serve as refugee shelters in Indonesia. Generally, } \\
\text { refugees in Pekanbaru City and Makassar City were } \\
\text { only transiting, while the main destination was } \\
\text { Australia. However, the Australian Government's } \\
\text { strict policies resulted in refugees being held in } \\
\text { Indonesia for many years. This research then } \\
\text { examines how the protection of refugees in } \\
\text { Pekanbaru City and Makassar City towards the } \\
\text { granting of refugee rights granted by the } \\
\text { Government and international organizations } \\
\text { regarding the status of refugees so far. The author } \\
\text { uses empirical/sociological legal research methods, } \\
\text { which are conducted by observational research, by } \\
\text { conducting surveys, and empirical or socio-legal } \\
\text { approaches, namely through field observations, } \\
\text { interviews, and literature studies. The results of this } \\
\text { study found that Indonesia has respected the } \\
\text { provisions of international law in protecting } \\
\text { refugees in Indonesia. The handling of refugees in } \\
\text { Indonesia For the most part, it has worked well in } \\
\text { granting refugee rights under the provisions of } \\
\text { international conventions on refugee status. }\end{array}$ \\
\hline
\end{tabular}

\section{A. Introduction}

The protection of refugees is an obligation of every country. Recipient countries are willing to accept refugees who have long felt insecure, threatened, and oppressed in their home countries. ${ }^{1}$ The issue of providing

\footnotetext{
${ }^{1}$ Sigit Riyanto, “Urgensi Legislasi Hukum Pengungsi Dan Kendalanya Di Indonesia," Jurnal Hukum Internasional 2, no. 1 (2004): 67.
} 
protection and assistance to refugees has become an international problem and has been formulated in the form of the 1951 Convention on the Status of Refugees and the 1967 Protocol.

The history of the arrival and existence of refugees in Indonesia has been started since $1975^{2}$ which started with the arrival of boat people from Vietnam $^{3}$. The traces of the early history of refugees from Vietnam can still be seen on Galang Island, an island with an area of $80 \mathrm{Km}^{2}(8,000 \mathrm{Ha})$ which is located 350 meters southeast of Rempang Island, and is one of the islands under the authority of Batam City, Riau Islands. Galang Island was previously designated by the United Nations as a place for 'boat people', namely Vietnamese citizens who fled their country when the war raged. The refugees from Vietnam left their country with makeshift boats, many of whom were stranded on several islands and waters of the Riau Islands, and were arrested by the Indonesian government. The boat people first landed in Indonesia on 25 May 1975 on Pulau Laut, Bunguran, Natuna Islands. ${ }^{4}$ Followed later, around 4,000 boat people fled to Anambas Island. The rest are scattered on Bintan Island, Pengibu Island, and the surrounding islands. ${ }^{5}$

Indonesia is not a party to the 1951 Convention and until now Indonesia has not ratified the 1951 Convention on the Status of Refugees and the 1967 Protocol. However, by not ratifying it, this does not mean that Indonesia can let go and be indifferent to the problem of refugees. Because there are principles of international law that must be obeyed by Indonesia. One of them is the principles of asylum which are related to the aspect of protecting human rights. ${ }^{6}$ In the principle of asylum, there is an obligation to respect the principle of non-refoulement. This principle by some legal experts falls into the category of Jus Cogens. The principle of non-refoulement means that it is prohibited to expel political asylum seekers to their country of origin. ${ }^{7}$ Article 33 of the 1951 Convention states that the substance of the principle of non-

\footnotetext{
${ }^{2}$ Herlina Yosepina Sihombing, "Kebijakan Indonesia Dalam Perlindungan Pencari Suaka Dan Pengungsi Pasca Kebijakan Turn Back the Boat Pemerintahan Tony Abbott," Journal of International Relations 5, no. 4 (2019): 601.

${ }^{3}$ M. Riadhussyah, "Tanggung Jawab Indonesia Sebagai Negara Transit Bagi Pengungsi Anak Berdasarkan Hukum Internasional,” Jurnal Hukum Ius Quia Iustum 23, no. 2 (2016): 240.

${ }^{4}$ Moh. Rosyid, "Genosida Etnis Muslim Rohingya Dan Partisipasi Indonesia Dalam Bina Damai," Al-Adyan: Jurnal Studi Lintas Agama 14, no. 2 (2019): 163.

${ }^{5}$ Manda Firmansyah, "Kisah 'Manusia Perahu' Pengungsi Vietnam Di Indonesia," 2019, https://bit.ly/3h2QHw6.

${ }^{6}$ Wagiman, Hukum Pengungsi Internasional (Jakarta: Sinar Grafika, 2012).

7 Aryuni Yuliantiningsih, "Perlindungan Pengungsi Dalam Perspektif Hukum Internasional Dan Hukum Islam,” Jurnal Dinamika Hukum 13, no. 1 (2013): 167. 
refoulement is the guarantee of a State not to expel or return a refugee in any way to his country of origin where his life and freedom are threatened. ${ }^{8}$

The Jus Cogens concept is defined as the primary source of legal norms that govern international relations. Although there are principles of international law "treaties may neither impose obligations on, nor create legal entitlements for, third states (pacta tertiis nec nocent nec prosunt)" namely international treaties, in this case, the 1951 Convention and the 1967 Protocol on the status of refugees do not impose obligations on Indonesia as a third country, it does not mean that there is no international standard of treatment and a national standard of treatment in treating refugees who are living in a third country. International standards emphasize the treatment of foreigners must be guided by international standards. ${ }^{9}$ Meanwhile, the national standard for treating foreigners must be treated the same as citizens under the laws of each country. Because Indonesia has not yet ratified the 1951 Convention, the Indonesian Government does not have the authority to determine the status of refugees ${ }^{10}$, so that arrangements on refugee issues are determined by UNHCR following the mandate of the 1950 UNHCR Statute.

Indonesia, which is not a destination country for refugees and only a transit country, so far Indonesia has not felt an interest in ratifying the 1951 Geneva Convention and the 1967 Additional Protocol. However, as part of the international community, Indonesia has so far shown good faith in respecting protection provisions for refugees that have become world law.

This study will explain the implementation of international legal provisions related to the Protection of Refugees in Refugee Camps in Indonesia. In this case, the author presents several facts about the protection and handling of refugees in Pekanbaru City, Riau Province, which is located on the island of Sumatra, and in Makassar City which is also the capital of South Sulawesi Province. The author uses an empirical/sociological legal research method, which is carried out by observational research, by conducting a survey, and an empirical or socio-legal approach, namely through field observations, interviews, and literature review.

\footnotetext{
8 Atik Krustiyati, "Kebijakan Penanganan Pengungsi Di Indonesia: Kajian Dari Konvensi Pengungsi 1951 Dan Protokol 1967," Law Review 12, no. 2 (2012): 174.

9 Arsensius, "Perlindungan Orang Asing Dalam Hukum Internasional," Jurnal Varia Bina Civika, no. 75 (2019): 1.

${ }^{10}$ Agastya Fatchur Royyan, Sri Lestari Rahayu, and Ayub Torry Satriyo Kusumo, "Urgensi Indonesia Meratifikasi the Convention Relating to the Status of the Refugees 1967 Dan Protocol New York 1967 Mengenai Pengungsi Internasional," Belli Ac Pacis 4, no. 1 (2018): 34.
} 


\section{B. Discussion}

Indonesia is in the development of the flow of refugees, not a destination country for refugees. According to a statement from the United Nations High Commissioners for Refugees (UNHCR), Indonesia is generally only used as a transit country for refugees and asylum seekers. ${ }^{11}$ As a country that is not bound by the Geneva Conventions of 1951 and the 1967 Protocol (mandate refugees), the determination of refugee status in Indonesia is at the UNHCR, while for countries that are bound by the two international instruments, the determination of refugee status is under the control of that country (statutory refugees).

The main destination of these refugees according to UNHCR is Australia. Australia, like other developed countries, has an attractive pull factor for the arrival of migrants to their country, namely a safe life and a high level of welfare. The multiethnic community life that has grown up in Australia makes it easier for refugees and asylum seekers to adapt. In addition, there is a belief among refugees and asylum seekers that it is easier to gain refugee status in Australia than in other countries, and this leads them to try to come to Australia in various ways. Several asylum seekers have tried to come directly to Australia by using wooden boats illegally as boat people. ${ }^{12}$ However, the recent policy changes issued by Australia regarding asylum seekers and refugees are known as the turn back the boat policy, and the refusal to resettlement for refugees has increased the number of asylum seekers and refugees who have to be detained in Indonesia. Based on UNHCR data, until the end of December 2019, the cumulative number of refugees in Indonesia was recorded at 13,657 people from 45 countries and more than half of the population came from Afghanistan. ${ }^{13}$ The refugees were placed in thirteen immigration detention centers (Rudenim) and various shelters in several provinces/districts/cities in Indonesia, including Pekanbaru City and Makassar City.

According to the perspective of international law, Indonesia has the right as an independent country, namely to exercise its sovereignty and determine whether or not it is acceptable to accept refugees who enter Indonesian territory. This is because Indonesia is not a country that has ratified the 1951 Refugee Convention and the 1967 Refugee Protocol. Indonesia currently has

\footnotetext{
11 Siciliya Mardian Yo'el, “Kajian Yuridis Perlindungan Pengungsi Di Indonesia Setelah Berlakunya Peraturan Presiden Republik Indonesia Nomor 125 Tahun 2016 Tentang Penanganan Pengungsi Dari Luar Negeri,” Journal Diversi 2, no. 2 (2016): 464.

${ }^{12}$ Adirini Pujayanti, "Isu Pencari Suaka Dalam Hubungan Bilateral Indonesia-Australia," Info Singkat Hubungan Internasional 6, no. 4 (2014): 6.

${ }^{13}$ UNHCR, “UNHCR Di Indonesia,” 2020, https://www.unhcr.org/id/unhcr-di-indonesia. 364
} 
a legal basis regarding the protection and regulation of refugees or asylum seekers in Indonesia, namely Presidential Regulation No. 125/2016.

\section{Refugees Protection in Pekanbaru City}

Pekanbaru City is the capital and largest city in Riau Province, Indonesia. This city is one of the largest economic centers on the island of Sumatra and is a city with a high rate of growth, migration, and urbanization. ${ }^{14}$ Geographically, Pekanbaru city has a strategic position on the East Sumatra Crossline, connected with several cities such as Medan, Padang, and Jambi, with an administrative area, flanked by Siak Regency in the north and east, while the western and southern parts by Kampar Regency.

Pekanbaru City is one of 13 cities that currently have Immigration Detention Centers (Rudenim) in Indonesia. Based on Article 1 Number 15 of Law Number 9 of 1992 concerning Immigration, it is stated that immigration quarantine is a temporary shelter for foreigners who are subject to the process of expulsion or deportation or other immigration measures. Based on this law, the term Immigration Quarantine was recognized as the initial form of the Immigration Detention Center (Rudenim), which was later formed in Pekanbaru City based on the Decree of the Minister of Justice and Human Rights of the Republic of Indonesia Number M.01.PR.07.04 of 2004 concerning the Organization and Administration of the Immigration Detention Center (Rudenim).

During the administration of President Joko Widodo, the government issued a policy for handling refugees through Presidential Regulation Number 125 of 2016 concerning Handling of Refugees from Abroad based on implementing the provisions of Article 27 paragraph (2) of Law Number 37 of 1999 concerning Foreign Relations. Article 33 to Article 39 in the Presidential Regulation, regulates provisions regarding the authority to supervise immigration by Rudenim. The authority of the Rudenim is to carry out immigration monitoring of refugees and asylum seekers which includes: when found, in the shelter and outside the shelter, being dispatched to the destination country, voluntary repatriation, and deportation. Therefore, based on their duties and functions, the Pekanbaru Rudenim is also given the authority to handle refugees in their working area. Initially, the refugees in Pekanbaru City were accommodated at the Pekanbaru City Rudenim, but according to the Circular of the Directorate General of Immigration of the Ministry of Law and Human Rights Number IMI-UM.01.01-2827 regarding Returning the Function of the Immigration Detention Center, then the

\footnotetext{
${ }^{14}$ Darmawati, "Determinasi Registrasi Penduduk Di Kota Pekanbaru," Teroka Riau 8, no. 2 (2008): 61 .
} 
Pekanbaru Immigration Detention Center no longer accommodates the refugees because the Rudenim is returned to its original function per Article 1 number 33 of Law Number 6 the Year 2011 concerning Immigration.

The existence of refugees in Pekanbaru City will be described by the author by explaining the existence of immigrant asylum seekers who began to dominate Pekanbaru City from the beginning of their arrival in 2015 until their existence in 2018. Since 2015 Riau Province has been used as a holding area for immigrants from various countries. They are refugees or asylum seekers who come from countries that are raging and are not safe. Their number continues to increase from year to year and is increasingly easy to find in various corners of the city of Pekanbaru. Based on Berita Harian Pekanbaru (the Pekanbaru Daily News) on Wednesday, February 11, 2015, it was reported that there were around 900 refugees in the city of Pekanbaru, who came from various countries dominated by the Middle East. ${ }^{15}$ The immigrants consist of 300 people who have been placed in the Pekanbaru Immigration Detention Center (Rudenim) and 600 others scattered in various places under the supervision of the Class I Immigration Office of Pekanbaru City. Then it continued into 2016, 1,043 refugees lived in the city of Pekanbaru. Their presence often creates unrest for the community. Especially since the news circulated of crimes or prostitution involving refugees. From data collected at the Regional Office of the Ministry of Law and Human Rights (Kanwil Kemenkum HAM) Riau Province, until early 2016 there were 1,043 immigrants in Pekanbaru. They are stationed in eight locations and come from 10 countries.

The first location that was used as a shelter for the immigrants was IDC Pekanbaru. At that location, there were 147 immigrants from Afghanistan, 21 people from Iran, 21 people from Pakistan, 2 people from Iraq, 4 people from Palestine, and 3 people from Bangladesh, so that the total number of 182 people. The second location, at the Satria Hotel there were 147 immigrants from Afghanistan, 14 people from Pakistan, nine people from Iraq, 30 people from Palestine, and three people from Somalia, bringing the total to 216 people. The third location at Wisma D'Cops contains a total of 136 immigrants from Afghanistan. The fourth location at Hotel Rina consists of 80 people from Afghanistan, three people from Iran, 63 people from Iraq, 30 people from Palestine, and 3 from Sudan, bringing a total of 184 people.

The fifth location in Siak Resort is that there are 58 people from Afghanistan and 2 from Iran, for a total of 60 people. The locations of the six

\footnotetext{
${ }^{15}$ Yudha Manggala P. Putra, "Pekanbaru Menampung 900 Pengungsi Imigran,” Portal berita online Republika, n.d., https://www.republika.co.id/berita/nasional/daerah/15/02/11/njl6gopekanbaru-menampung-900-pengungsi-imigran. 366
} 
Badr Lugina are 33 people from Afghanistan and 8 from Iran, bringing the total to 41 people. The seventh location in the Wisma Panel consists of 70 people from Afghanistan, two from Iran, nine from Pakistan, six from Somalia, 28 from Sudan, and 116 people from Myanmar. The eighth location in Wisma Novri consists of 13 people from Afghanistan, four from Iran, two from Pakistan, 12 from Iraq, 34 from Palestine, 5 from Somalia, 34 from Myanmar, and 4 people from Sri Lanka, bringing the total to 108 people. Overall, the total number of immigrants based on country, namely from Afghanistan is 697 people, Iranian 40 people, Pakistan 27 people, Iraqi 93 people, Palestine 99 people, Somalia 14 people, Sudan 31 people, Myanmar 35 people, Sri Lanka 4 people and Bangladesh 3 people.

In 2017 there were 1,176 immigrants in Pekanbaru, about 70 percent of whom were refugees and the rest were still in the process of seeking asylum. They mostly came from Afghanistan, which reached 930 people. Then there were 35 people from Iraq, 20 people from Iran, 59 people from Palestine, 40 people from Sudan, 40 people from Myanmar Rohingya, 21 people from Somalia, 24 people from Pakistan, 3 people from Sri Lanka, 2 people from Bangladesh, and from Jordan and Syria 1 each. . Those who have received refugee status from UNHCR and asylum seekers live in eight community houses $(\mathrm{CH})$ in Pekanbaru City. A total of 239 refugees and asylum seekers from abroad in Pekanbaru, Riau, consisted of children under 17 years of age.

Those who have received refugee status from UNHCR and asylum seekers now live in eight community houses $(\mathrm{CH})$ in Pekanbaru City. Their existence to interact with Pekanbaru residents cannot be avoided because they can be active outside the room until $20.00 \mathrm{WIB}$ and have to be in $\mathrm{CH}$. Among the Community Houses in Pekanbaru are Wisma Panel Rumbai, Siak Resort, Hotel Rina, Hotel Satria, D 'Cops, Rudenim, Wisma Indah, Hotel Tasoya, Wisma Novry. They are now placed in eight community houses $(\mathrm{CH})$ located in Pekanbaru City and one Rudenim. Especially in the Rudenim Kota Pekanbaru, there were around 282 refugees recorded. They come from eight countries, including Afghanistan, Bangladesh, Iraq, Iran, Pakistan, Palestine, Somalia, and Sudan. These countries are known to be partly experiencing conflicts, which have displaced their citizens.

Some of the refugees are also no longer placed in the Immigration Detention Center (Rudenim) Pekanbaru, especially since many of them have families and have children. The number of immigrants that are quite large and continue to increase from year to year, which is not comparable to the increase in the provision of housing facilities for refugees, asylum seekers, and immigrants who want to get protection in Pekanbaru City, causing the capacity of the Immigration Detention Center (Rudenim) in Pekanbaru City finally 
overload. This has been exacerbated by the increase in the number of residents due to the birth of refugee babies living in that place. The most worrying thing is the inability to accommodate the detention centers in Pekanbaru City which will increase overcapacity considering the number of immigrants who are increasing every year. This is also what the author has described in the previous chapter. It was recorded that from November 2017 to May 2018 there were 10 births from the foreigner. In 2018, based on data reports obtained from the International Organization for Migration (IOM) until January 31, 2018 , there were 1,174 refugees and asylum seekers. The IOM explained that of this number, 750 of them were refugees and 424 asylum seekers. The number based on gender, namely 339 women and 835 men.

IOM explained that because Pekanbaru did not have a special shelter for refugees, the Regional Government, therefore, appointed a special place by determining a location called the Community House $(\mathrm{CH})$. Based on the processed data in this research, matters relating to the shelter of refugees from abroad in Pekanbaru City are determined by the Mayor of Pekanbaru by issuing a Decree on the recommendation of the National Unity and Political Committee (Kesbangpol), henceforth IOM will facilitate the shelter by renting from the owner of the inn.

Based on data obtained from the Pekanbaru Rudenim, the number of refugees who were under the supervision of the Pekanbaru Rudenim as of July 29, 2020, was 979 people. The refugees are currently scattered in several shelters and come from several countries, namely Afghanistan, Iraq, Iran, Myanmar, Palestine, Somalia, Pakistan, and Sudan, with the following details:

Table 1. Recapitulation of Refugees in Pekanbaru City As of July 29, 2020

\begin{tabular}{|c|c|c|c|c|c|c|c|c|c|c|}
\hline \multirow{2}{*}{ No. } & Place & AFG & IRQ & IRN & MMR & PLE & SOM & PAK & SDN & TOTAL \\
\cline { 3 - 11 } & Wisma Indah & 91 & 0 & 0 & 0 & 0 & 8 & 0 & 6 & 105 \\
\hline 2 & Hotel Satria & 109 & 0 & 0 & 0 & 0 & 0 & 6 & 0 & 115 \\
\hline 3 & Wisma D'Cops & 110 & 2 & 0 & 0 & 0 & 0 & 1 & 0 & 113 \\
\hline 4 & Hotel Rina & 0 & 0 & 0 & 0 & 0 & 0 & 0 & 0 & 0 \\
\hline 5 & Wisma Novri & 36 & 0 & 0 & 33 & 6 & 5 & 2 & 0 & 82 \\
\hline 6 & $\begin{array}{c}\text { Wisma Siak } \\
\text { Resort }\end{array}$ & 130 & 0 & 0 & 0 & 0 & 0 & 3 & 0 & 133 \\
\hline
\end{tabular}




\begin{tabular}{|c|c|c|c|c|c|c|c|c|c|c|}
\hline 7 & Wisma Fanel & 82 & 0 & 1 & 1 & 0 & 6 & 5 & 19 & 114 \\
\hline 8 & Rumah Tasqya & 125 & 4 & 2 & 0 & 9 & 0 & 0 & 0 & 140 \\
\hline 9 & Wisma Orchid & 145 & 16 & 9 & 0 & 6 & 0 & 0 & 0 & 176 \\
\hline 10 & $\begin{array}{c}\text { Pengungsi } \\
\text { Mandiri (Tidak } \\
\text { Difasilitasi IOM) }\end{array}$ & 1 & 0 & 0 & 0 & 0 & 0 & 0 & 0 & 1 \\
\hline TOTAL & $\mathbf{8 2 9}$ & $\mathbf{2 2}$ & $\mathbf{1 2}$ & $\mathbf{3 4}$ & $\mathbf{2 1}$ & $\mathbf{1 4}$ & $\mathbf{2 0}$ & $\mathbf{2 7}$ & $\mathbf{9 7 9}$ \\
\hline
\end{tabular}

Note:

AFG : Afghanistan

IRQ : Iraq

IRN : Iran

MMR : Myanmar

PLE : Palestine

SOM : Somalia

PAK : Pakistan

SDN : Sudan

Source: Rumah Detensi Imigrasi Pekanbaru City, 2020.

Based on the data in table 1 above, it shows that of the 979 refugees who are under the supervision of the Pekanbaru Rudenim, the majority of them are refugees originating from Afghanistan with a total of 829 people or about $85 \%$ of the total number of refugees in Pekanbaru. Then the number of refugees from Myanmar is 34 people or about 3.5\%, Sudan 27 people or about $2.8 \%$, Iraq 22 people or about 2.2\%, Palestine 21 people or about $2.1 \%$, Pakistan 20 people or about $2 \%$, Somalia 14 people or about $1.4 \%$, and Iran 12 people or about $1.2 \%$.

Regarding the current shelter for refugees in Pekanbaru, according to Presidential Regulation No. 125 of 2016 concerning Handling of Refugees from Abroad, Pekanbaru Immigration Detention Center is no longer accommodating refugees. The shelter for the refugees is currently determined by the Pekanbaru City Government by the provisions of Article 26 Paragraph (1) of the Presidential Regulation. According to the results of an interview with Mrs. Tri Rahayu as Head of the Sub-Section for Administration and Reporting at the Pekanbaru Immigration Detention Center, a shelter for refugees from abroad in Pekanbaru City was established by the Mayor of Pekanbaru by issuing a Decree on the recommendation of the Kesbangpol, 
followed by IOM who facilitated the shelter by contract with the owner of the inn. According to Mrs. Tri Rahayu, currently, there are 9 shelters for refugees from abroad under the supervision of the Pekanbaru Rudenim, with information that 8 shelters are filled and 1 shelter is vacated because the contract period has ended. Based on Table 1 above, it can be seen that the 9 refugee shelters are Wisma Indah, Hotel Satria, Wisma D'Cops, Hotel Rina, Wisma Novri, Wisma Siak Resort, Wisma Fanel, Rumah Tasqya, and Wisma Orchid. Meanwhile, refugees with independent refugee status who are not facilitated by IOM are allowed to rent their place at their own expense as long as they follow the rules that apply to refugees in general. The placement of the refugees in the shelter generally goes through the handover procedure by the Pekanbaru Rudenim to an official appointed by the Pekanbaru City Government accompanied by an official report of the handover of refugees by attaching proof of receipt of items belonging to the refugees except for immigration documents in the form of travel documents, residence permit documents, and Visa.

All designated shelters are located in the city of Pekanbaru, which mingles directly with the people of Pekanbaru City. Then, with one location that has expired its contract or lease period, the consequence is that the refugees who are in that place must move to another holding location whose condition is no longer adequate with the number of residents that are more than the availability of existing rooms or rooms. This can be seen from outside the refugee camps. Many of the refugees and their families live in shelter terraces that have been converted into emergency rooms with makeshift barriers. Thus, the location of the refugee camp looks more like a slum area that disturbs the aesthetics of the city. This can be seen at several existing shelter points. Apart from being in shelters, refugees who have the status of independent refugees whose needs are not covered by IOM are allowed to live separately, by finding a place to live on their own.

\section{Refugees Protection in Makassar City}

Makassar City is a municipality and also the capital city of South Sulawesi Province. Makassar City is one of the fourth largest cities in Indonesia and also the largest in the Eastern Region of Indonesia. As a service center in Eastern Indonesia (KTI), Makassar City also plays an important role as a center for trade and services, a center for industrial activities, a center for government activities, a node for goods and passenger transportation services, both land, sea and air, as well as a center for education and health services. Administratively, Makassar City has about 14 sub-districts and 143 urban 
villages. ${ }^{16}$ Makassar City has a strategic position because it is directly adjacent to the Makassar Strait which is located between the islands of Kalimantan and Sulawesi in Indonesia. This strait is also based on a geographical description that connects the North Sulawesi Sea to the Java Sea in the south.

As one of the largest cities in the country of Indonesia, Makassar City has become a stopover destination for asylum seekers and refugees in Indonesia. This is evidenced by the increase in the number of refugees and asylum seekers entering the Makassar City area which tends to continue to increase every year. There are several reasons why over time more refugees are transiting in Makassar City. First, the openness of the local community and local government which was felt by the refugees in recent years in accepting the presence of refugees. Second, the existence of a representative office of UNHCR and IOM in Makassar City is a consideration for refugees in the hope of making it easier for them to be placed in third countries with the assistance of these international organizations. Third, there are adequate refugee shelter facilities in Makassar City for the refugees.

Refugees in the Makassar City area are under the supervision authority of the Makassar Rudenim. Makassar City itself is one of 13 cities in Indonesia that has detention centers, where the duties and functions are the same as the detainees in Pekanbaru City. Based on the Decree of the Minister of Justice and Human Rights of the Republic of Indonesia Number M.01.PR.07.04 of 2004 concerning the Organization and Work Procedure of the Immigration Detention Center (Rudenim), Makassar Rudenim's working areas are spread across four provinces, namely Southeast Sulawesi Province, South Sulawesi Province, Maluku Province, and North Maluku Province.

In 2016, the number of refugees in Makassar City was 1,906, consisting of 1,330 men and 576 women. This number continues to increase with the presence of refugees who are placed in third countries, returned to their home countries, or the arrival of new refugees in Makassar City. Until October 31, 2019, the number of refugees in Makassar City reached 1,724 people who were under the supervision of the Makassar Rudenim. The majority of them are refugees originating from Afghanistan with a total of 1,140 people (or about $66.1 \%$ ) of the total number of refugees in Makassar. Then the number of refugees from Myanmar is 175 people (or about 10.1\%), followed by Somalia 142 people (8.2\%), Sudan 66 people (3.8\%), Iran 56 people (3.2\%), Iraq 43 people (2.5\%), Pakistan 34 people (2\%), Sri Lanka 28 people (1.6\%), Ethiopia 25 people $(1.4 \%)$, Palestine 8 people $(0.5 \%)$, Yemen 5 people $(0.3 \%)$, Eritrea 1 person $(0.06 \%)$ and Egypt 1 person $(0.06 \%)$.

\footnotetext{
${ }^{16}$ Pemprov Sulsel, "Profil Kota Makassar,” 2020, https://sulselprov.go.id/pages/info_lain/22.
} 
Regarding the return function of Rudenim, the Makassar Rudenim no longer accommodates the refugees because the Rudenim is returned to their original function, following Article 1 number 33 of Law Number 6 the Year 2011 concerning Immigration. Based on the contents of the circular, it is explained that the circular letter was issued as a follow-up to the dialogue between the Government of the Republic of Indonesia and the Committee on the Protection of the Rights of Migrant Workers and Members of Their Families in Geneva, Switzerland, on 05-06 September 2017, and a meeting between the Director-General of Immigration and the IOM Delegation. which was attended by the Chief of Mission IOM, Mark Getchell, and Senior Program Coordinator, Dejan Micevski, on Monday, 25 June 2018, at the office of the Director-General of Immigration, to discuss follow-up policies on tightening aid from donor countries for the handling of refugees in Indonesia. The circular letter also explained that the grounds of efficiency and budget savings by IOM, conveyed the hope that refugees and asylum seekers are currently in detention can be placed in a temporary shelter or region. This is in line with the contents of Presidential Regulation Number 125 of 2016 concerning the Handling of Refugees from Abroad.

As for the shelter for refugees currently determined by the Makassar City Government, by the provisions of Article 26 Paragraph (1) of Presidential Decree Number 125 of 2016. Until October 31, 2019, refugees in Makassar City are spread over 25 refugee shelters, namely 155 Guesthouse-A, 155 Guesthouse-B, 155 Guesthouse-C, 155 Guesthouse-D, Bugis House, D'Win Homestay, Ida Guesthouse 2, Kirani Guesthouse, Pondok Elite-A, Pondok Elite-B, Pondok Maryam, Pondok Nugraha, Pondok Re-Re , Pondok Reski Jaya, Pondok Yaspis, Wisma Bajirupa, Wisma Budi, Wisma Bungaya (Mustika-I), Wisma D'Khanza, Wisma Favorite, Wisma KPI, Wisama MSM, Wisma Maysara, Wisma Mustika 2, and Wisma Mustika 3. As for one a refugee from Afghanistan is in police custody because he is caught in a legal problem. The details of the number of refugees in each refugee camp are as follows: 
Table 2. Recapitulation of Refugees in Each Refugee Shelter in Makassar City for the Period of 31 October 2019

\begin{tabular}{|c|c|c|c|c|c|c|c|c|c|c|c|c|c|c|c|}
\hline \multirow{2}{*}{ No. } & \multirow{2}{*}{ Place } & \multicolumn{13}{|c|}{ Citizenship } & \multirow{2}{*}{ Total } \\
\hline & & AFG & MMR & SOM & SDN & IRN & IRQ & PAK & LKA & ЕTH & PSE & YEM & ERI & EGY & \\
\hline 1 & Rudenim Makassar & 0 & 0 & 0 & 0 & 0 & 0 & 0 & 0 & 0 & 0 & 0 & 0 & 0 & 0 \\
\hline 2 & Tahanan Polisi & 1 & 0 & 0 & 0 & 0 & 0 & 0 & 0 & 0 & 0 & 0 & 0 & 0 & 1 \\
\hline 3 & 155 Guesthouse-A & 37 & 0 & 5 & 1 & 1 & 0 & 0 & 0 & 2 & 0 & 0 & 0 & 0 & 46 \\
\hline 4 & 155 Guesthouse-B & 43 & 4 & 1 & 3 & 0 & 0 & 0 & 0 & 0 & 0 & 0 & 0 & 0 & 51 \\
\hline 5 & 155 Guesthouse-C & 20 & 2 & 0 & 0 & 0 & 0 & 0 & 0 & 0 & 0 & 0 & 0 & 0 & 22 \\
\hline 6 & 155 Guesthouse-D & 68 & 0 & 4 & 0 & 0 & 0 & 0 & 0 & 0 & 0 & 1 & 0 & 0 & 73 \\
\hline 7 & Bugis House & 99 & 2 & 14 & 3 & 5 & 0 & 0 & 0 & 0 & 0 & 0 & 0 & 0 & 123 \\
\hline 8 & D'Win Homestay & 1 & 12 & 4 & 1 & 0 & 0 & 0 & 0 & 2 & 0 & 0 & 0 & 0 & 20 \\
\hline 9 & Ida Guesthouse 2 & 42 & 0 & 18 & 5 & 5 & 0 & 0 & 0 & 0 & 0 & 0 & 0 & 0 & 70 \\
\hline 10 & Kirani Guesthouse & 76 & 0 & 0 & 0 & 0 & 0 & 3 & 0 & 0 & 1 & 0 & 0 & 0 & 80 \\
\hline 11 & Pondok Elite-A & 37 & 0 & 0 & 4 & 0 & 0 & 1 & 0 & 0 & 0 & 0 & 0 & 0 & 42 \\
\hline 12 & Pondok Elite-B & 48 & 0 & 1 & 0 & 0 & 0 & 0 & 0 & 0 & 0 & 0 & 0 & 0 & 49 \\
\hline 13 & Pondok Maryam & 13 & 2 & 3 & 2 & 0 & 0 & 0 & 0 & 0 & 0 & 0 & 0 & 0 & 20 \\
\hline 14 & Pondok Nugraha & 87 & 4 & 22 & 19 & 16 & 13 & 0 & 0 & 3 & 0 & 0 & 1 & 0 & 164 \\
\hline 15 & Pondok Re-Re & 100 & 22 & 13 & 8 & 3 & 0 & 16 & 0 & 1 & 0 & 1 & 0 & 1 & 165 \\
\hline 16 & Pondok Reski Jaya & 70 & 3 & 1 & 0 & 0 & 0 & 4 & 0 & 0 & 0 & 0 & 0 & 0 & 78 \\
\hline 17 & Pondok Yaspis & 29 & 2 & 2 & 0 & 0 & 0 & 0 & 0 & 3 & 0 & 0 & 0 & 0 & 36 \\
\hline 18 & Wisma Bajirupa & 31 & 16 & 10 & 0 & 2 & 11 & 0 & 0 & 0 & 0 & 2 & 0 & 0 & 72 \\
\hline 19 & Wisma Budi & 0 & 24 & 1 & 0 & 0 & 0 & 0 & 0 & 1 & 0 & 0 & 0 & 0 & 26 \\
\hline 20 & Wisma Bungaya (Mustika-I) & 20 & 14 & 0 & 0 & 0 & 0 & 0 & 7 & 0 & 0 & 0 & 0 & 0 & 41 \\
\hline 21 & Wisma D'Khanza & 25 & 16 & 2 & 2 & 4 & 0 & 0 & 0 & 5 & 0 & 1 & 0 & 0 & 55 \\
\hline 22 & Wisma Favorite & 31 & 11 & 2 & 0 & 2 & 1 & 0 & 0 & 0 & 0 & 0 & 0 & 0 & 47 \\
\hline 23 & Wisma KPI & 80 & 12 & 15 & 2 & 2 & 4 & 1 & 3 & 0 & 7 & 0 & 0 & 0 & 126 \\
\hline 24 & Wisama MSM & 11 & 21 & 10 & 1 & 7 & 5 & 0 & 13 & 5 & 0 & 0 & 0 & 0 & 73 \\
\hline 25 & Wisma Maysara & 93 & 14 & 6 & 2 & 5 & 9 & 5 & 0 & 3 & 0 & 0 & 0 & 0 & 137 \\
\hline 26 & Wisma Mustika 2 & 35 & 0 & 0 & 2 & 4 & 0 & 0 & 5 & 0 & 0 & 0 & 0 & 0 & 46 \\
\hline 27 & Wisma Mustika 3 & 43 & 6 & 0 & 8 & 0 & 0 & 4 & 0 & 0 & 0 & 0 & 0 & 0 & 61 \\
\hline & Total & 1.140 & 175 & 142 & 66 & 56 & 43 & 34 & 28 & 25 & 8 & 5 & 1 & 1 & \begin{tabular}{|l|}
1.724 \\
\end{tabular} \\
\hline
\end{tabular}

Note:

AFG: Afghanistan

MMR: Myanmar

SOM: Somalia

SDN: Sudan

IRN: Iran

IRQ: Iraq

SIR: Pakistan

LKA: Sri Lanka

ETH: Ethiopia

PSE: Palestine 
YEM: Yemen

ERI: Eritrea

EGY: Egypt

Source: Data from the Makassar City Immigration Detention Center for the period of 31 October 2019

\section{Comparison of Refugee Protection in Pekanbaru City and Makassar City}

Regulations related to the rights and obligations of every refugee are regulated in the 1951 Convention which outlines several refugee rights, namely ${ }^{17}$ : (a) The right not to be treated in a discriminatory manner, Articles 3 and 4 of the 1951 Convention emphasize that countries participating in the convention cannot treat refugees based on discrimination politics, whether based on race, religion, country of origin, or color; (b) Property rights, Articles 13, 14 and 30 of the 1951 Convention provide that a refugee has the same right to own or possess property rights, both movable and immovable and to keep it like any other person. In addition, refugees can also transfer their assets to the country where they will reside; (c) The right to organize, states parties to the convention must recognize the freedom of refugees to associate by establishing associations, including trade associations as long as the association is non-profit and non-political (Article 15 of the 1951 Convention); (d) Right to litigate in court. If a refugee experiences a case and wants to resolve it through a judicial body, then they must be considered the same as other citizens of the country. This means that they have the freedom to file their claims at the court where they live. Even if needed they can get legal assistance (Article 16 of the 1951 Convention);

(e) The right to work, the 1951 Convention grants the right to a refugee who has been permanently placed in a country and has been recognized according to law to obtain employment and to establish a trade company and other casual employment in accordance with the applicable provisions (Articles 17, 18 and 19); (f) The right to social welfare, Articles 20 and 22 of the 1951 Convention stipulate that every refugee will be able to enjoy the rights to social welfare, such as the right to work, housing, and wages for the work they do; (g) Right to education and teaching, every refugee has the right to receive equal treatment with other citizens of the State to obtain primary school education, including the right to exemption from certain tuition fees including the right to obtain scholarships (Article 22); (h) Right to freedom of

\footnotetext{
${ }^{17}$ Rahayu, Kholis Roisah, and Peni Susetyorini, "Perlindungan Hak Asasi Manusia Pengungsi Dan Pencari Suaka Di Indonesia," Masalah-Masalah Hukum 49, no. 2 (2020): 207. 374
} 
movement, every refugee has the widest possible freedom to choose the area in which they will settle, as long as that choice is still within the territory of the country where he is located (Article 26 of the 1951 Convention); (i) Right to identification and travel documents, Articles 27 and 28 of the 1951 Convention stipulate that every refugee is entitled to identity papers and travel documents out of the territory of the country where he is placed, except for reasons of security and public interest. These issued travel documents are recognized by the States parties to the Convention; (j) The right of nonrefoulement, that the state is not allowed to expel or return refugees in any way to the borders of areas where their life or freedom will be threatened because of their race, religion, membership in certain social groups or because of their political opinion (Article 33 paragraph (1) ) Convention 1951); (k) The right to personal status, under Article 12 of the 1951 Convention, the personal status of refugees is regulated according to the law in which they are domiciled. If they do not have a domicile, their status is governed by the law where they are placed (place of residence). The right to personal status includes rights related to marriage.

In addition to the rights of refugees mentioned above, the convention also regulates the obligations of each refugee as stated in Article 2 of the 1951 Convention that "...Every refugee has duties to the country in which he finds himself, which require in particular that he conform to its laws and regulations as well as to measures taken for maintenance of public order...". This means that every refugee is obliged to comply with all laws and regulations or provisions to create public order in the country where he is placed. As previously explained, even though Indonesia has not ratified the 1951 Convention and the 1967 Protocol, as a global citizen, Indonesia is still obliged to implement human rights law principles that must be respected, such as the principle of the state's obligation to protect every person whose life is threatened and the rights of everyone to receive humanitarian protection wherever he is. As a nation that upholds a high level of human rights, Indonesia has so far received and protected refugees residing in its territory. The following is the result of research related to the fulfillment of several refugee rights in Pekanbaru City and Makassar City.

a. Fulfillment of the Right to Education and Teaching

Based on the results of an interview with Mrs. Tri Rahayu as Head of the Sub-Section for Administration and Reporting at the Pekanbaru Immigration Detention Center, currently, there are refugee children who are under the supervision of the Pekanbaru Rudenim who are following the learning education system in formal schools to fulfill human rights against children, namely the Right to Above Children. Education and everything related to 
education costs are facilitated by IOM in collaboration with the Pekanbaru City Education Office. Pekanbaru City itself is the first city in Indonesia to officially allow refugee children to attend formal schools and serve as a pilot area. This policy was taken after the Task Force for Handling Overseas Refugees at the Coordinating Ministry for Political, Legal, and Security Affairs (Kemenko Polhukam RI) held a meeting to discuss the handling of refugees in Pekanbaru in August 2019. During the meeting, it was agreed that several conditions must be met by refugee children to attend formal schools. First, the child has a refugee card issued by UNHCR. Second, get a recommendation from the local Rudenim in coordination with the Ministry of Law and Human Rights. Third, get a guarantee letter and commitment to supporting education costs from the institution that sponsors the presence of refugees. Fourth, a letter of recommendation from the sponsoring institution for every refugee child who will go to school. ${ }^{18}$ The policy to allow refugee children to attend public elementary schools in Pekanbaru City is also based on a letter from the Ministry of Education and Culture and the Directorate of Immigration Enforcement and Monitoring of the Ministry of Law and Human Rights, as well as the coordination result of the Pekanbaru City Education Office. ${ }^{19}$

As of October 2019, as many as 81 children who have met the school requirements based on IOM Pekanbaru's recommendations have attended formal schools in Pekanbaru. Out of the 12 public elementary schools (SDN) proposed by IOM, only eight were declared by the Pekanbaru City Education Office to be able to accommodate refugee children. ${ }^{20}$ Schools that accept refugee children include SDN 159 (20 children), SDN 56 (22 children), SDN 141 (eight children), SDN 7 (three children), SDN 170 (seven children), SDN 48 (seven children), SDN 190 (seven children), and SDN 182 (seven children). ${ }^{21}$ These refugee children study at these state schools with the same language of instruction, namely Bahasa Indonesia and use the same school uniforms as local students. The subjects were not differentiated at all so that

\footnotetext{
18 Harian Nasional, "Pekanbaru Daerah Pertama Membolehkan Anak Pencari Suaka Bersekolah," 2019, http://www.harnas.co/2019/08/27/pekanbaru-daerah-pertamamembolehkan-anak-pencari-suaka-bersekolah.

${ }^{19}$ Pindainews.com, "Indonesia Evaluasi Kebijakan Anak Imigran Bersekolah Di Pekanbaru," 2019.

${ }^{20}$ Pizaro Gozali Idrus, "81 Anak Pencari Suaka Sekolah Di SD Negeri Indonesia, Proses Pembelajaran Menggunakan Bahasa Indonesia," 2019, https://www.aa.com.tr/id/dunia/-81anak-pencari-suaka-sekolah-di-sd-negeri-indonesia-/1604201.

${ }^{21}$ Melki Pangaribuan, “Anak-Anak Pencari Suaka Bersekolah Di SD Negeri Pekanbaru,” 2019, http://www.satuharapan.com/read-detail/read/anak-anak-pencari-suaka-bersekolah-di-sdnegeri-pekanbaru. 
these refugee children were not differentiated from local students at the school. However, refugee children cannot be given a student identification number and certificate when they graduate, because to get this, several documents must be obtained, such as a family card and Indonesian birth certificate. When they graduate, these refugee children will only get a Graduation Certificate from the school leadership. However, based on the results of an interview with Mr. Rafki Syukri as the UNHCR representative in Pekanbaru, this is not a problem, because what refugee children need is to normalize their lives. They need to get enthusiasm and motivation again to get up early, wear school uniforms, go to school, and study together at school.

UNHCR Pekanbaru City has also advocated for higher education to gain access to higher education for refugees in the city. In 2019, one of the private universities in Pekanbaru City, namely the Universitas Islam Riau, has opened itself to accept refugee children to study at the campus after advocacy carried out by the UNHCR Representative of Pekanbaru City with the Rector of the Universitas Islam Riau. The campus is also willing to provide scholarships for refugees who are studying at the Universitas Islam Riau. Based on the agreement between UNHCR and the campus, some refugee children should be able to start studying in the 2020 academic year, but due to the Covid-19 Pandemic, there was a temporary delay.

The conditions of refugee children in Makassar City are almost the same as in Pekanbaru City. The Makassar City Government has so far been highly committed to the refugees residing in the Makassar City area. Refugee children have been allowed to attend several public schools, even though their status is not the same as Indonesian citizens because they do not have a student ID number, so they cannot get a diploma. However, at least, they have been allowed to get the same learning as other students.

So far, in addition to formal schools, to fulfill the right to education for refugee children in the Makassar City area, IOM has established a collaborative relationship with LSKP (Institute for Public Policy Studies), one of the NGOs in Makassar City, to empower refugee children. IOM and LSKP have agreed to implement an education program for refugee children aged 618 years. However, in practice, it turns out that many children outside this age category also attend and take part in lessons in the classroom, although the teachers still focus more on teaching children who fall into that age category. ${ }^{22}$ The practice of implementing non-formal education separates the female class

\footnotetext{
22 Syahrul, "Internalisasi Pendidikan Multikultural Dan Inklusif Pada Anak Pengungsi Internasional Di Kota Makassar," JPK (Jurnal Pancasila Dan Kewarganegaraan) 4, no. 3 (2019): 25-34, https://doi.org/http://dx.doi.org/10.24269/jpk.v4.n3.2019.pp25-34.
} 
from the male class, known as the Boy Shelter class and the Woman Shelter class.

\section{b. Fulfillment of Non-Refoulement Rights}

Implementation of handling refugees in the regions is generally based on Presidential Decree 125/2016. The implementation of the non-refoulement principle in Pekanbaru City is based on the results of the author's research and interviews with Mrs. Tri Rahayu (Rudenim Pekanbaru) and Mr. Rafki Syukri (UNHCR Pekanbaru) has gone quite well. According to Mrs. Tri Rahayu, the local government of Pekanbaru City has never evicted refugees who came to Pekanbaru, either at the Discovery, Shelter, Security, and Immigration Supervision stages. The case of community rejection of refugees had occurred at the beginning of their arrival in Pekanbaru City because the social reintegration process was not good enough at that time due to cultural and cultural differences between the local community and the refugees. However, stakeholders in this case Immigration, Kesbangpol (National Unity Agency, Politics), Police / TNI, and Community Leaders, under Presidential Regulation Number 125 of 2016 concerning Handling Refugees from Abroad, together with UNHCR and IOM try to provide understanding to the community, so that currently refugees can be in Pekanbaru and can mingle with the community. Mr. Rafki Syukri also strengthened this statement, that currently, the people of Pekanbaru have accepted the presence of refugees in Pekanbaru City.

The implementation of the non-refoulement principle in Makassar City is not much different from that in Pekanbaru City. The Makassar City Government and residents have upheld this principle and accepted the presence of the refugees. However, based on the results of interviews with Mr. Hamanzah, Head of the Makassar Rudenim Health and Care Section from the Makassar City Rudenim, the presence of refugees in Makassar has disturbed residents around the shelter several times. This is due to cases of rape, use of narcotics, gigolos, sodomy, adultery with the wives of residents, the spread of Shiites, and others. This has an impact on the concerns of residents about the whereabouts of the refugees.

Refugees in Makassar also hold demonstrations almost every year in front of the UNHCR, IOM, Rudenim, and the Office of the Governor of South Sulawesi. ${ }^{23}$ Their demands are generally related to the clarity of their placement to third countries, improvement of facilities, and fulfillment of

\footnotetext{
${ }^{23}$ Hardani Triyoga and Irfan, "Tuntut Kejelasan Nasib, Imigran Rohingya Demo Gubernur Sulsel," 2020, https://www.viva.co.id/berita/nasional/1264721-tuntut-kejelasan-nasib-imigranrohingya-demo-gubernur-sulsel. 
basic rights. However, if you refer to the regulations in Indonesia, demonstrations by foreign nationals are not allowed, so that the refugees who held the demonstration violated Law Number 9 of 1998 concerning Freedom to Express Opinions in Public.

\section{c. Fulfillment of the Right to Freedom of Movement}

Based on the provisions of Article 24 of Presidential Decree 125/2016, refugees residing in Indonesia are accommodated in temporary shelters or accommodation stipulated by the Regent/Mayor. According to Mrs. Tri Rahayu as Head of the Sub-Section for Administration and Reporting at the Pekanbaru Immigration Detention Center, a shelter for refugees from abroad in Pekanbaru City is determined by the Mayor of Pekanbaru by issuing a Decree on the recommendation of Kesbangpol (National Unity Agency, Politics), then the International Organization for Migration (IOM) which facilitates the shelter by contracting with the owner of the inn. While in these shelters, IOM also facilitated all the needs of the refugees. Meanwhile, refugees who are not under the assistance of international agencies or are called independent refugees generally look for their place to live at their own expense (independent living).

Regarding the right to freedom of movement, the Pekanbaru City and Makassar City Government has so far provided freedom of movement for refugees to travel and mingle with the general public while they are still in Indonesian territory. However, specifically for refugees in shelters, Article 25 letter h of Presidential Decree 125 of 2016 regulates an order that binds the refugees, which in its implementation, one of the rules made both in Pekanbaru City and Makassar City, is the imposition of a curfew. This means that there is a time limit for refugees to leave the shelters in the two cities, which is regulated until 21.00 local time. Violation of the curfew will be penalized in stages. The first violation will be subject to an oral warning, the second violation will be given a written warning, and the third violation will be subject to disciplinary action by temporarily transferring the refugee to a Detention Center. In addition, the refugees are also not allowed to drive motorized vehicles such as motorbikes and cars because they do not have a driver's license in Indonesian territory. In the supervision of refugees in Pekanbaru City and Makassar City, the executor of supervision of the refugees is under the authority of the city's Rudenim. The obligation attached to refugees in the context of surveillance is the obligation to report monthly to the Head of the local Immigration Detention Center to get a stamp on a special identity card while in the shelter. Refugees who do not report themselves for 3 (three) consecutive times without an acceptable reason, will be temporarily 
placed in the Immigration Detention Center under the provisions of Article 36 of Presidential Decree 125 of 2016.

\section{d. Fulfillment of the Right to Work}

Regarding the right to work for refugees, it has not been regulated in Presidential Decree 125 of 2016. However, based on the results of an interview with Mr. Yance Tamaela as the UNHCR representative in Makassar City, refugees in Makassar City are still not allowed by the Government to get access to work. Mr. Rafki Syukri as the UNHCR representative in Pekanbaru said a different matter. According to him, there are no rules that prohibit and there are no rules that allow a refugee to work in Indonesia. However, according to Pak Rafki, in practice so far, the refugees will be constrained by the documents required by the company. When asked about the right to work for refugees, Mrs. Tri Rahayu as Head of Sub-Section for Administration and Reporting at the Pekanbaru Immigration Detention Center stated that refugees in Pekanbaru were not allowed to work in both the formal and non-formal sectors.

\section{e. Fulfillment of the Right to Health Services}

The Practices carried out in Pekanbaru City and Makassar City show that every refugee has been given access to health services. IOM in these two cities has collaborated with the Health Office, Puskesmas, and hospitals closest to the evacuation sites. All costs for this health service have been borne by IOM. This guarantee is provided in addition to the meager monthly allowance that IOM gives refugees each month. However, refugees still have to pay their travel costs to access treatment. If hospitalized, all costs incurred will be borne by IOM. However, if refugees want to seek treatment at the Puskesmas or other health service providers who do not cooperate with IOM, then the costs incurred by the refugees themselves must be borne by the refugees.

\section{Conclusion}

The number of refugees under the supervision of Rudenim Pekanbaru as of 29 July 2020 was 979 people. Meanwhile, the number of refugees who are under the supervision of the Makassar Rudenim as of date31 October 2019 reached 1,724 people. Regarding the Right to Education and Teaching for Refugees in Pekanbaru City and Makassar City, the two cities allow refugee children to attend formal schools and serve as pilot areas. Fulfilling NonRefoulment Rights, it was found that in these two cities so far the refugees have never been evicted. Fulfilling the Right to Freedom of Movement, the Municipal Government of Pekanbaru and Makassar City have provided 
freedom of movement, however, specifically for refugees in shelters, there is a curfew. The fulfillment of the Right to Work is known that according to the UNHCR representative in Pekanbaru there are no rules that prohibit and there are no rules that allow refugees to work in Indonesia. It is different with the refugees in Makassar City who are still not allowed by the Government to get access to jobs. However, in practice so far, the refugees will be constrained by the documents required by the company. The right to health services in the city was found that IOM in the two cities had collaborated with the Health Office, Puskesmas, and hospital closest to the evacuation sites. All costs for this health service have been borne by IOM.

Therefore, even though Indonesia is not a party to conventions relating to refugee status, as part of the world community, Indonesia has respected the provisions of international law in protecting refugees in Indonesia. The handling of refugees in Indonesia For the most part, it has worked well in granting refugee rights under the provisions of international conventions on refugee status.

\section{References}

Arsensius. "Perlindungan Orang Asing Dalam Hukum Internasional." Jurnal Varia Bina Civika, no. 75 (2019): 1.

Darmawati. "Determinasi Registrasi Penduduk Di Kota Pekanbaru." Teroka Riau 8, no. 2 (2008): 61.

Firmansyah, Manda. "Kisah 'Manusia Perahu' Pengungsi Vietnam Di Indonesia," 2019. https://bit.ly/3h2QHw6.

Idrus, Pizaro Gozali. "81 Anak Pencari Suaka Sekolah Di SD Negeri Indonesia, Proses Pembelajaran Menggunakan Bahasa Indonesia," 2019. https://www.aa.com.tr/id/dunia/-81-anak-pencari-suaka-sekolahdi-sd-negeri-indonesia-/1604201.

Krustiyati, Atik. "Kebijakan Penanganan Pengungsi Di Indonesia: Kajian Dari Konvensi Pengungsi 1951 Dan Protokol 1967.” Law Review 12, no. 2 (2012): 174.

Nasional, Harian. "Pekanbaru Daerah Pertama Membolehkan Anak Pencari Suaka Bersekolah," 2019. http://www.harnas.co/2019/08/27/pekanbarudaerah-pertama-membolehkan-anak-pencari-suaka-bersekolah.

Pangaribuan, Melki. "Anak-Anak Pencari Suaka Bersekolah Di SD Negeri Pekanbaru," 2019. http://www.satuharapan.com/read-detail/read/anakanak-pencari-suaka-bersekolah-di-sd-negeri-pekanbaru.

Pindainews.com. "Indonesia Evaluasi Kebijakan Anak Imigran Bersekolah Di Pekanbaru," 2019. 
Pujayanti, Adirini. "Isu Pencari Suaka Dalam Hubungan Bilateral IndonesiaAustralia." Info Singkat Hubungan Internasional 6, no. 4 (2014): 6.

Putra, Yudha Manggala P. "Pekanbaru Menampung 900 Pengungsi Imigran." Portal berita online Republika, n.d. https://www.republika.co.id/berita/nasional/daerah/15/02/11/njl6gopekanbaru-menampung-900-pengungsi-imigran.

Rahayu, Kholis Roisah, and Peni Susetyorini. "Perlindungan Hak Asasi Manusia Pengungsi Dan Pencari Suaka Di Indonesia." MasalahMasalah Hukum 49, no. 2 (2020): 207.

Riadhussyah, M. "Tanggung Jawab Indonesia Sebagai Negara Transit Bagi Pengungsi Anak Berdasarkan Hukum Internasional.” Jurnal Hukum Ius Quia Iustum 23, no. 2 (2016): 240.

Riyanto, Sigit. "Urgensi Legislasi Hukum Pengungsi Dan Kendalanya Di Indonesia." Jurnal Hukum Internasional 2, no. 1 (2004): 67.

Rosyid, Moh. "Genosida Etnis Muslim Rohingya Dan Partisipasi Indonesia Dalam Bina Damai." Al-Adyan: Jurnal Studi Lintas Agama 14, no. 2 (2019): 163.

Royyan, Agastya Fatchur, Sri Lestari Rahayu, and Ayub Torry Satriyo Kusumo. "Urgensi Indonesia Meratifikasi the Convention Relating to the Status of the Refugees 1967 Dan Protocol New York 1967 Mengenai Pengungsi Internasional." Belli Ac Pacis 4, no. 1 (2018): 34.

Sihombing, Herlina Yosepina. "Kebijakan Indonesia Dalam Perlindungan Pencari Suaka Dan Pengungsi Pasca Kebijakan Turn Back the Boat Pemerintahan Tony Abbott." Journal of International Relations 5, no. 4 (2019): 601.

Sulsel, Pemprov. "Profil Kota Makassar," 2020. https://sulselprov.go.id/pages/info_lain/22.

Syahrul. "Internalisasi Pendidikan Multikultural Dan Inklusif Pada Anak Pengungsi Internasional Di Kota Makassar." JPK (Jurnal Pancasila Dan Kewarganegaraan) 4, no. 3 (2019): 25-34. https://doi.org/http://dx.doi.org/10.24269/jpk.v4.n3.2019.pp25-34.

Triyoga, Hardani, and Irfan. "Tuntut Kejelasan Nasib, Imigran Rohingya Demo Gubernur Sulsel," 2020. https://www.viva.co.id/berita/nasional/1264721-tuntut-kejelasan-nasibimigran-rohingya-demo-gubernur-sulsel.

UNHCR. "UNHCR Di Indonesia," 2020. https://www.unhcr.org/id/unhcr-diindonesia.

Wagiman. Hukum Pengungsi Internasional. Jakarta: Sinar Grafika, 2012. Yo'el, Siciliya Mardian. "Kajian Yuridis Perlindungan Pengungsi Di Indonesia Setelah Berlakunya Peraturan Presiden Republik Indonesia 
Nomor 125 Tahun 2016 Tentang Penanganan Pengungsi Dari Luar Negeri." Journal Diversi 2, no. 2 (2016): 464.

Yuliantiningsih, Aryuni. "Perlindungan Pengungsi Dalam Perspektif Hukum Internasional Dan Hukum Islam." Jurnal Dinamika Hukum 13, no. 1 (2013): 167. 
